\title{
First occurrence of Neralsia splendens (Borgmeier) (Hymenoptera: Figitidae) as parasitoids of Cyrtoneurina pararescita (Couri) (Diptera: Muscidae) in a rural area in Brazil
}

\section{Carlos Henrique Marchiori}

Federal Institute Goiás, Morrinhos, Goiás, Brazil; chmarchiori@yahoo.com.br

Received 15 November 2013; revised 16 December 2013; accepted 11 January 2014

Copyright (C) 2014 Carlos Henrique Marchiori. This is an open access article distributed under the Creative Commons Attribution License, which permits unrestricted use, distribution, and reproduction in any medium, provided the original work is properly cited. In accordance of the Creative Commons Attribution License all Copyrights (C) 2014 are reserved for SCIRP and the owner of the intellectual property Carlos Henrique Marchiori. All Copyright @ 2014 are guarded by law and by SCIRP as a guardian.

\section{ABSTRACT}

Figitidae behave as primary parasitoids of dipterous larvae that develop in the feces of cattle and agricultural pests such as fruit flies (Tephritidae) on fruit, Zaprionus indianus Gupta (Diptera: Drosophilidae) in fig cultivations, and Dettmeria euxestae Borgmeier, 1935 (Hymenoptera: Figitidae) in Euxesta eluta Loew, 1996 (Diptera: Otitidae) in corn. Neralsia splendens (Borgmeier 1935) (Hymenoptera: Figitidae), is a larval parasitoid of Diptera. The muscid genus Cyrtoneurina Giglio-Tos is one of the most abundant Phaoniine groups in the Neotropics. It may be of some hygienic importance because of the semidomestic habits of the adults of several species and the environment in which the coprophagous larvae develop. In the Neotropical region, few studies have been conducted on this group. This paper reports the first occurrence of $N$. $s p$ lendens parasitizing $C$. pararescita in a rural area in Brazil. The study was conducted at the farm of the Veterinary and Zootechnics School of the Federal University of Goiás, in Goiânia, Brazil, next to corn and sorghum plantations. The dipterous pupae were obtained by means of the flotation method. They were individually placed in gelatin capsules until the emergence of the dipterous insects and/or their parasitoids. Two specimens were collected from 26 pupae of $C$. pararescita. The percentage of parasitism was $0.35 \%$. The present study is the first in the world to report the occurrence of $N$. splendens parasitizing $C$. pararescita.

\section{KEYWORDS}

Insecta; Diptera; Biocontrol; Goiás; Brazil

\section{INTRODUCTION}

The flies included in the infra-order Muscomorpha have medical and veterinary importance, since they may produce myiasis and act in carrying pathogens to man and animals [1]. They have been found to carry more than 100 species of disease-causing organisms such as bacteria, protozoa and helminths [2].

Parasitoids are responsible for reducing the populations of flies that proliferate on various substrates. Evaluation of these species for natural control over these insects is important for enabling studies to aim towards subsequent selection of species for use in biological control programs [3].

It is known that the superfamily Cynipoidea comprises around 20,000 species and that approximately $75 \%$ of them are parasitoids of holometabolous insects [4]. In the Neotropical region, few studies have been conducted on this group [4].

Figitidae behave as primary parasitoids of dipterous larvae that develop in the feces of cattle and agricultural pests such as fruit flies (Tephritidae) on fruit and Dettmeria euxestae Borgmeier, 1935 (Hymenoptera: Figitidae) in Euxesta eluta Loew, 1996 (Diptera: Otitidae) on corn. Moreover, they reduce the economic losses caused by the melon fly and Zaprionus indianus Gupta (Diptera: Drosophilidae) in figs. The first published record of occurrences of $Z$. indianus in the Americas was in persimmons in Santa Isabel, São Paulo, Brazil. Its polyphagy and relatively fast lifecycle in hot climates have contributed 
towards its establishment and dispersion throughout Brazil [5]. A loss of 50\% of fig production in the state of São Paulo, Brazil, due to this fly, has been recorded [5].

Members of the parasitic wasp family Figitidae are early internal to late external parasitoids of endopterygote insect larvae. The egg is deposited inside a young host larva, which continues to develop normally despite the presence of the parasite inside. After some period of feeding internally, the parasite larva eventually emerges from the moribund host, before the latter pupates, and spends the last one or two instars feeding externally on the host's remains [6]. Because growth of the host larva is not halted by the parasite attack, figitids are classified as koinobiont parasitoids [5].

Neralsia Cameron 1883 is a figitid genus distributed in the Americas, comprising around 30 species. Neralsia is potentially important for controlling Diptera Cyclorrhapha $[7,8]$.

The muscid genus Cyrtoneurina Giglio-Tos is one of the most abundant Phaoniine groups in the Neotropics. It may be of some hygienic importance because of the semidomestic habits of the adults of several species and the environment in which the larvae develop [9], in which it causes economic losses to agriculture and livestock.

The aim of the present study was to report on a new host for Neralsia splendens (Borgmeier, 1935) (Hymenoptera: Figitidae) in a rural area in Brazil.

\section{MATERIAL AND METHODS}

This study were conducted at the farm of the Veterinary and Zootechnics School of the Federal University of Goiás, in the municipality of Goiânia (16 $40^{\circ}$ 'S and $\left.49^{\circ} 16^{\prime \prime W}\right)$, Brazil, next to corn and sorghum plantations. Every fortnight, 10 plates of fecal cake (of approximately $3 \mathrm{~kg}$ each) were produced from fresh bovine feces that were collected immediately after defecation in pastures of Brachiaria brizantha (Hochst ex. A. Rich) and in corrals. The material was collected in plastic buckets and was homogenized. It was then placed in 10 round plastic supports of $20 \mathrm{~cm}$ in diameter, with a hole to allow rainwater to drain away. This methodology was used for precise determination of the time between the emission of the fecal cake and its collection. The feces remained exposed (five in the pastures and five in the corrals) for 15 days. After this period, the feces were taken to the laboratory for extraction of pupae by means of the flotation method.

The pupae were removed with the aid of a sieve; they were counted and individually stored in gelatin capsules (number 00) until the flies and/or parasitoids emerged. The parasitoids and flies that emerged were identified with the aid of a stereoscopic microscope and were conserved in $70 \%$ alcohol.

The adult parasitoids were identified using the keys of [7] and the hosts were identified in accordance with [10].
The percentage parasitism was calculated as the number of parasitized pupae divided by the total number of pupae collected, and multiplied by 100 .

\section{RESULTS AND DISCUSSION}

Between March and July 2012, 26 pupae of Cyrtoneurina pararescita (Couri, 1995) (Diptera: Muscidae) were collected from bovine feces, from which two specimens of $N$. splendens emerged. The parasitism rate was $0.35 \%$, probably due to the availability of resources, host density, searching capacity of the parasitoids or proximity of agricultural areas. Forests and agricultural areas are places of refuge and emergence for these parasitoids.

Neralsia splendens has the potential for host range expansion and thus may have a non-target impact on other beneficial parasitoids of Diptera.

Neralsia splendens has been collected from pupae of Sarcophagula occidua (Fabricius, 1794) (Diptera: Sarcophagidae), both in Brazil and in Argentina [8,11-13].

The hosts of figitids are typically larvae of Diptera Cyclorrhapha that develop in living plants or fungi, or in decomposing organic matter such as rotting fruit, carrion and dung. The hosts attacked include aphid-feeding larvae of Chamaemyiidae (Diptera: Cyclorrhapha), aphid and psyllid parasitoids in Braconidae and Encyrtidae (Hymenoptera: Apocrita), and aphid-feeding larvae of Neuroptera $[14,15]$.

C. pararescita has previously been found to be parasitized by the following parasitoids: Nasonia vitripennis (Walker) (Hymenoptera: Pteromalidae), Pachycrepoideus vindemmiae (Rondani) (Hymenoptera: Pteromalidae) [16], Paraganaspis egeria (Hymenoptera: Figitidae), Spalangia nigra Latrielle, Spalangia nigroaenea Curtis (Hymenoptera: Pteromalidae) and Triplasta atrocoxalis Ashmead (Hymenoptera: Figitidae) [17].

Among the means for controlling flies, chemical insecticides are the most widely used. However, these may lose their efficiency as populations become resistant to them [8]. The appearance of resistance to insecticides explains the growing need to introduce alternative control programs aimed towards insect control [18].

As a possibility for controlling these insects, natural regulators such as parasitoids, which are agents responsible for reducing the populations of insect pests, can be used.

\section{CONCLUSION}

Neralsia splendens has the potential for host range expansion and thus may have a non-target impact on other beneficial parasitoids of Diptera. Thus, $N$, splendens may be a viable alternative for keeping this pest in long-term control programs. The present study is the first in the world to report the occurrence of $N$. splendens parasitiz- 
ing C. pararescita.

\section{REFERENCES}

[1] Marcondes, B. (2010) Entomologia Médica e Veterinária. Editora Atheneu, São Paulo.

[2] Greenberg, B. (1971) Flies and disease-Ecology, classification and biotic association. Princeton University Press, New Jersey,

[3] Marchiori, C.H., Vieira, C.I.S., Caldas, E.R., Teixeira, F.F., Silva, C.G. and Linhares, A.X. (2000) Dípteros muscóides associados com fezes bovinas e seus parasitóides em Goiás. Arquivo Brasileiro de Medicina Veterinária e Zootecnia, 52, 354-356. http://dx.doi.org/10.1590/S0102-09352000000400011

[4] Hanson, P.E. and Gauld, I.D. (1995) The Hymenoptera of Costa Rica. Oxford University Press, Oxford.

[5] Askew, R.R. and Shaw, M.R. (1986) Parasitoid communities: their size, structure and development. Academic Press, London.

[6] Ronquist, F. and Nieves-Aldrey, J.L. (2001) A new subfamily Figitidae (Hymenoptera: Cynipoidea). Zoological Journal of the Linnean Society, 133, 483-494. http://dx.doi.org/10.1111/j.1096-3642.2001.tb00636.x

[7] Díaz, N. and Gallardo, F. (1995) Aportes al conocimiento de Neralsia splendens en la Argentina (Hymenoptera: Figitidae). Revista de la Sociedad Entomológica Argentina, 54, 74.

[8] Díaz, N. and Gallardo, F. (1996) Sobre cinipoideos del Brasil, parasitoides de dipteros estercoleros (Hymenoptera: Cynipoidea). Revista de la Sociedad Entomológica Argentina, 55, 127-129.

[9] Snyder, F.M. (1954) A revision of Cyrtoneurina giglio-Tos, with notes on related genera (Diptera, Muscidae). Bulletin of the American Museum of Natural History, 103, 517-464.

[10] Carvalho, C.J.B, Moura, M.O. and Ribeiro, P.B. (2002) Chave para adultos de dípteros (Muscidae, Fanniidae, Anthomyiidae) associados ao ambiente humano no Brasil. Revista Brasilera de Entomologia, 46,107-114.
http://dx.doi.org/10.1590/S0085-56262002000200001

[11] Marchiori, C.H. and Linhares, A.X. (1999) Constância, dominância e freqüência mensal de dípteros muscóides e seus parasitóides (Hymenoptera e Coleoptera), associados a fezes frescas de bovinos, em Uberlândia, MG. Anais da Sociedade Entomológica do Brasil, 28, 375-387. http://dx.doi.org/10.1590/S0301-80591999000300002

[12] Marchiori, C.H. (2000) Parasitóides de estágios imaturos de dípteros sinantrópicos coletados em vários ambientes em Itumbiara-GO. Acta Scientiarum, 22, 655-666.

[13] Marchiori, C.H., Caldas, E.R. and Almeida, K.G.S. (2003) Parasitoids collected from artificial bovine dung pats exposes for different periods of time in Itumbiara, Goiás, Brazil. Acta Scientiarum, 25, 9-13.

[14] Couri, M.S. (1995) Uma nova espécie de Cyrtoneurina Gigllo-Tos do Brasil (Diptera, Muscidae). Revista Brasileira de Zoologia, 12, 229-232. http://dx.doi.org/10.1590/S0101-81751995000200001

[15] Ronquist, F. (1999) Phylogeny, classification and evolution of the Cynipoidea (Hymenoptera). Zoologica Scripta, 28, 139-164. http://dx.doi.org/10.1046/j.1463-6409.1999.00022.x

[16] Marchiori, C.H. and Silva Filho, O.M. (2007) New host for the parasitoid Pachycrepoideus vindemmiae (Rondani) (Hymenoptera: Pteromalidae) in Brazil. Arquivo Brasileiro de Medicina Veterinária e Zootecnia, 59, 271-272. http://dx.doi.org/10.1590/S0102-09352007000100046

[17] Marchiori, C.H., Silva, Filho. O.M., Milhomem, M.E.V. and Leles, A.S. (2007) Parasitoides de dípteros coletado em fezes de búfalos em uma propriedade rural em Itumbiara, Goiás. Arquivo Brasileiro de Medicina Veterinária e Zootecnia, 59, 1589-1592. http://dx.doi.org/10.1590/S0102-09352007000600038

[18] Silveira, G.A.R., Madeira, N.G., Azeredo-Espin, A.M. and Pavan, C. (1989) Levantamento d1e microhimenópteros parasitóides de dípteros de importância médico-veterinária no Brasil. Memórias do Instituto Oswaldo Cruz, 84, 505-510. http://dx.doi.org/10.1590/S0102-09352007000600038 